\title{
MATHEMATICAL JUSTIFICATION OF SENIOR HIGH SCHOOL STUDENTS IN STATISTICS
}

\author{
Masyita Putri Firdausy \\ Mathematics Education, Faculty of Mathematics and Natural Sciences, Universitas Negeri Surabaya

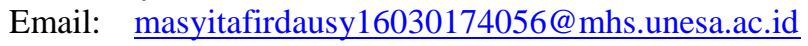 \\ Abdul Haris Rosyidi \\ Mathematics Education, Faculty of Mathematics and Natural Sciences, Universitas Negeri Surabaya \\ Email: abdulharis@unesa.ac.id
}

\begin{abstract}
Justification is the process of justifying a claim that is supported with evidence. Justification is the center of mathematics. Justification plays an important role in learning because it can help students improve understanding of mathematical concepts. By using a qualitative approach, this study aims to analyze the mathematical justification of high school students in solving problems on statistical topics. This research was conducted on 122 high school students by giving justification test questions on the topic of statistics resulted in $17 \%$ (21 students) included in the level justification level 3, 16\% (19 students) included in level 2, 47\% (47 students) included in level 1, and 20\% (25 students) the rest are included in level 0 . Further analysis was carried out to see the mathematical justification process by each level. The mathematical justification process consists of three stages, 1) the process of recognition; 2) the development process (building-with), and 3) understanding (awareness) process. Level 3 and level 2 students can recognize the problem and determine the right strategy to solve the problem, level 3 and level 2 students are also able to execute the strategy and interpret the results of the calculations they have done. The difference in level 3 and level 2 students lies in the understanding the concepts they have. Level 1 students can recognize problems and determine solution strategies. Although level 1 students can recognize and do calculations well, level 1 students fail in interpreting the results of calculations performed. While students who are level 0 are not able to recognize the problem, so level 0 students do not carry out the justification process.
\end{abstract}

Keywords: process of mathematical justification, level of mathematical justification, statistic

Abstrak

Justifikasi adalah proses pembenaran suatu klaim yang didukung dengan bukti-bukti. Justifikasi merupakan pusat dari matematika. Justifikasi berperan penting dalam pembelajaran karena dapat membantu siswa dalam meningkatkan pemahaman konsep matematika. Dengan menggunakan pendekatan kualitatif, penelitian ini bertujuan untuk menganalisis justifikasi matematis siswa SMA dalam menyelesaikan masalah pada topik statistika. Penelitian yang dilakukan terhadap 122 siswa SMA dengan memberikan soal tes justifikasi dengan topik statistika, menghasilkan 17\% (21 siswa) yang termasuk dalam tingkatan justifikasi level 3, 16\% (19 siswa) termasuk dalam level 2, 47\% (57 siswa) termasuk dalam level 1, dan 20\% (25 siswa) sisanya termasuk kedalam level 0. Analisis lebih lanjut dilakukan untuk melihat proses justifikasi matematis yang dilakukan oleh masing-masing level. Proses justifikasi matematis terdiri atas tiga tahapan, 1) proses pengenalan; 2) proses pembangunan; dan 3) proses pengartian. Siswa level 3 dan level 2 mampu mengenali masalah dan menentukan strategi yang tepat untuk menyelesaikan masalah tersebut, siswa level 3 dan level 2 juga mampu mengeksekusi strategi tersebut dan dapat mengartikan hasil perhitungan yang telah mereka lakukan. Perbedaan pada siswa level 3 dan level 2 terletak pada pemahaman konsep yang dimiliki. Siswa level 1 mampu mengenali masalah dan menentukan strategi penyelesaian. Meskipun siswa level 1 mampu mengenali dan melakukan perhitungan dengan baik, namun siswa level 1 gagal dalam mengartikan hasil perhitungan yang dilakukan. Sedangkan siswa yang termasuk level 0 tidak mampu mengenali masalah, sehingga siswa level 0 tidak melakukan proses justifikasi.

Kata Kunci: proses justifikasi matematis, level justifikasi matematis, statistika

\section{INTRODUCTION}

Mathematics is a discipline that examines and evaluates the validity of facts and proves the arguments (Chua, 2016). Mathematics itself always occurs in everyday life, so students need to learn and practice mathematical skills, including the ability to reason and justify mathematically. As stated in NCTM (2000) that in education, students will participate in justifying mathematically.

Justification is the center of mathematics (Lapointe, 2011). Lin (2016) states that mathematical justification is a series of arguments or reasons that indicate a presumption 
is true. In addition, Supriani et. al. (2019) states that the process of mathematical justification is a process of rational response in claiming the truth of an opinion. Then the mathematical justification can be interpreted as a process of constructing an argument to test the truth of a claim by using knowledge that has been proven before.

Jane Lo, et. al. (2008) states that with justification students can improve their understanding of mathematical concepts, so students can explain what they are thinking. This statement is also supported by Staples and Bartlo (2010) that the mathematical justification process directs students to be able to deepen their understanding and mathematical concepts because they require students to wrestle with various ideas and look for connections between ideas to get new views. In addition to increasing understanding of mathematical concepts, mathematical justification can also improve students' communication skills (Staples \& Bartlo, 2010). This is because, mathematical justifications made by students must be able to convince others (Hamidy \& Suryaningtyas, 2016) or in other words, mathematical justifications that have been prepared can persuade others if the claims and arguments submitted are true.

But unfortunately, there are still many students who have difficulty in justifying (Furinghetti \& Morselli, 2011). Even teachers still have difficulty in guiding students' justification process successfully (Chua, 2016). In general, teachers ask students to explain their justifications when students' answers are wrong but ask students to explain their justifications when their answers are often ignored (Glass \& Maher, 2004).

Students must be able to prove the truth of the claim or statement they submit by showing the arguments accompanied by evidence. This is included in one of the processes for justification. The justification process that has been carried out by students in approving statements, can describe the flow of students' thinking, and an explanation of why the statement is true (Pamungkas et. al, 2018). By knowing the flow of students' thinking can help teachers in analyzing problems or difficulties that students might face in justifying.

The following are three processes in mathematical justification based on Kidron \& Dreyfus (2010) and Pamungkas et. al. (2018).

1. Recognition is a process in which students recognize mathematical ideas that arise and recognize the problems presented.

2. Building-with is the process of combining the knowledge possessed by students to achieve the expected goals such as solving problems or justifying claims.

3. Awareness (understanding) is the process by which students determine a clear summary or conclusion by interpreting the results of calculations to answer the truth of an argument or claim.

In some studies, mathematical justification is classified into several groups or levels. Knowing the level of student justification can help the teacher in designing the problems or assignments given to the students. As one classification of mathematical justification levels proposed by Jane Lo et. al. (2008) which divides mathematical justifications into five levels,

1. Level 0. There are no answers or answers do not contain valid reasoning strategies.

2. Level 1. Justification is only descriptive or merely explains the steps.

3. Level 2. Some of the justifications contain erroneous mathematical concepts or contain insufficient details.

4. Level 3. Justification is mostly clear and conceptually correct but omitting some aspects.

5. Level 4. The justification is clear, complete and conceptually correct.

In this research, the focus of the topic raised is statistics. Statistics are an important part of the Mathematics curriculum in Indonesia (Rosidah et. Al., 2018). Statistics contains methods for organizing and summarizing information (Weiss, 2012). Justification in statistics combines ideas about data and opportunities that will lead to the conclusion and interpretation of results statistically (Garfield, 2002). Based on the description above, this study will discuss the mathematical justification of students in understanding problems in the context of statistics.

\section{METHODS}

This research used a qualitative approach to analyze the mathematical justification of high school students. Participants in this study were high school students in grade 10 and 11 in 2019/2020 with a total of 122 students. The study was conducted at one of the state high schools in Sidoarjo, East Java. Students were given tests on statistical topics to find out their mathematical justification level. The test questions were arranged based on the justification task type making decision proposed by Chua (2017). Making decision-justification tasks are tasks that offer choices in a mathematical condition and students are asked to choose one option to answer the problems given. This type of question was chosen because the component that is highlighted in this type of problem is the decision in determining which claims are supported or proven by arguments. As such the component is part of the justification level indicator (Table 1). Here are the test problems are given to students. 
[Test Problem]

Rangga will take a written test 8 times. Each test has a maximum score of 100 . Following are the scores obtained by Rangga in the first 7 tests: $84,82,74,64,86,91,72$

Which central tendency (mean, median, mode) did Rangga expect his teacher to use to calculate his final exam scores? Explain why that was chosen!

The results of student answers were analyzed to determine the level of justification. Indicators used to divide students into levels of mathematical justification were indicators compiled based on levels of justification proposed by Jane Lo et. al. (2008). The following are indicators of the level of mathematical justification.

Table 1. Indicator of Mathematical Justification Level

\begin{tabular}{|c|l|}
\hline Level & \multicolumn{1}{c|}{ Indicators } \\
\hline 0 & $\begin{array}{l}\text { Answers do not contain claims and do not contain } \\
\text { arguments }\end{array}$ \\
\hline \multirow{2}{*}{1} & The answer contains claims \\
\cline { 2 - 3 } & Answers do not contain arguments \\
\hline 2 & The answer contains claims \\
\cline { 2 - 3 } & $\begin{array}{l}\text { The answers contain arguments but the arguments } \\
\text { given are incorrect (there was a concept error or } \\
\text { calculation error) }\end{array}$ \\
\hline \multirow{2}{*}{3} & The answer contains claims \\
\cline { 2 - 3 } & $\begin{array}{l}\text { The answer contains partially correct arguments } \\
\text { (incomplete arguments) }\end{array}$ \\
\hline \multirow{2}{*}{4} & The answer contains claims \\
\cline { 2 - 2 } & $\begin{array}{l}\text { Answers contain arguments that are complete and } \\
\text { correct (clear, easy to follow, unambiguous) }\end{array}$ \\
\hline
\end{tabular}

After students were divided into levels of mathematical justification, from each level that appears was selected one student who would then be the subject of research. The selected subject was interviewed to analyze the mathematical justification process that they did. Indicators used to see students' mathematical justification process were indicators compiled based on a mathematical justification process proposed by Kidron \& Dreyfus (2010) and Pamungkas et. al. (2018). Following are indicators of the mathematical justification process,

Table 2. Indicators of Mathematical Justification Process

\begin{tabular}{|c|c|}
\hline Process & Indicators \\
\hline \multirow[t]{2}{*}{ Recognition } & $\begin{array}{l}\text { Students recognize the problem } \\
\text { (understand what is asked in the } \\
\text { problem) }\end{array}$ \\
\hline & $\begin{array}{l}\text { Students know the steps or strategies } \\
\text { that must be used to solve problems }\end{array}$ \\
\hline \multirow[t]{2}{*}{ Building-with } & $\begin{array}{l}\text { Students execute steps or strategies } \\
\text { correctly }\end{array}$ \\
\hline & $\begin{array}{l}\text { Students build an argument supported by } \\
\text { evidence of the results of calculations }\end{array}$ \\
\hline Awareness & $\begin{array}{l}\text { Students state that their claims are true } \\
\text { by concluding the arguments that have } \\
\text { been built }\end{array}$ \\
\hline
\end{tabular}

\section{RESULT AND DISCUSSION}

Based on tests that were given to the 122 middle school students in grades 10 and 11 , here are the results obtained,

Table 3. Research Data

\begin{tabular}{|c|c|c|c|c|c|c|}
\hline Level & $\mathbf{0}$ & $\mathbf{1}$ & $\mathbf{2}$ & $\mathbf{3}$ & $\mathbf{4}$ & Total \\
\hline Amount & 25 & 57 & 19 & 21 & - & 122 \\
\hline Percent & $20 \%$ & $47 \%$ & $16 \%$ & $17 \%$ & $0 \%$ & $100 \%$ \\
\hline
\end{tabular}

From each level that appears, one subject was chosen for further discussion.

\section{Level 3's Subject Mathematical Justification}

Students who were included in level 3 were students who made claims and included arguments accompanied by an 'estimate' of the eighth unknown test score and then calculated it with the central tendency. There were two types of answers given by students, namely by guessing what was the eighth score without any reason behind it and students who assumed the eighth score based on the calculation results.

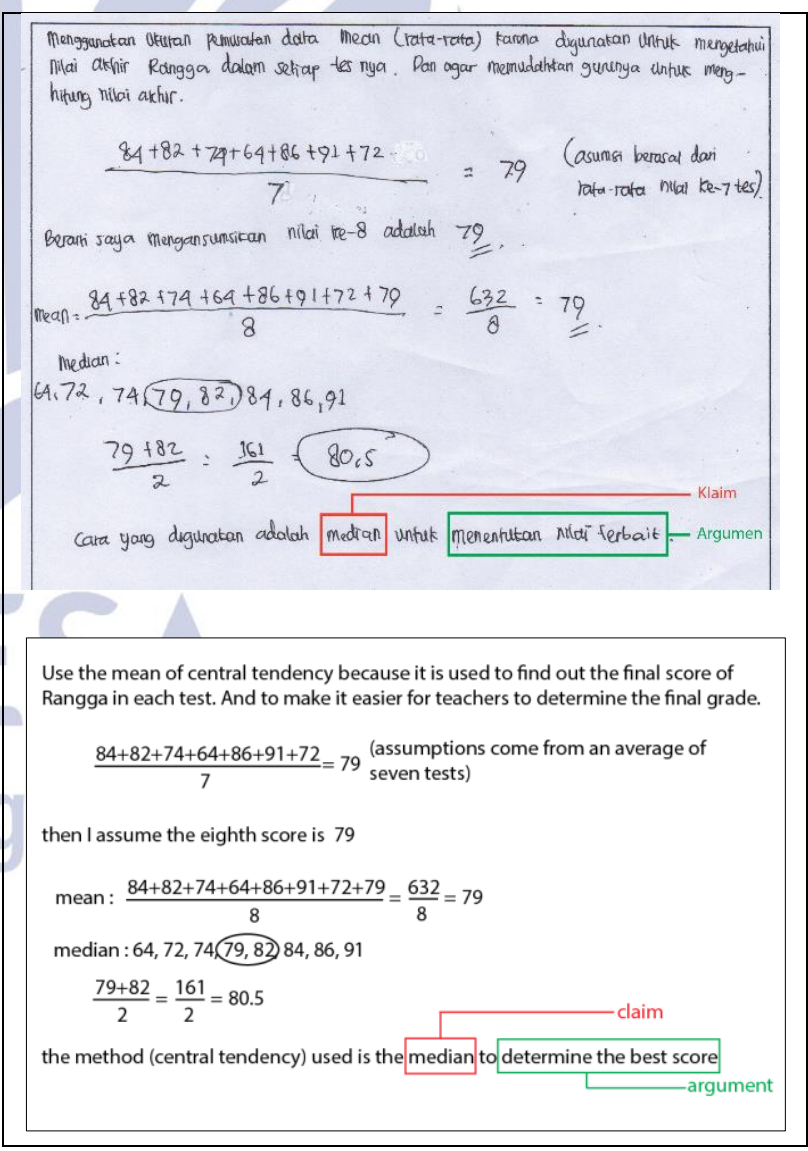

Figure 1. Level 3's Subject Work Result

Like the answers given by level 3's subject, which he gave reasons or used assumptions to determine the eighth score as shown in Figure 1. In the recognition process, the subject was expected to recognize the problem requested in 
the test problem. Level 3's subject could recognize problems well. As seen in the following interview excerpt.

\begin{tabular}{|c|c|c|}
\hline Researcher & & $\begin{array}{l}\text { If you are asked to write down what is } \\
\text { known or asked, what do you want to } \\
\text { write? }\end{array}$ \\
\hline Subject L3 & & $\begin{array}{l}\text { For the information, this is } n \text { (data) as } \\
\text { many as } 8 \text {, with a maximum value of } \\
\text { 100, then } 7 \text { data have been obtained } \\
\text { along with the scores. What is asked } \\
\text { is the final score }\end{array}$ \\
\hline Researcher & & $\begin{array}{l}\text { Please, try reading the question one } \\
\text { more time }\end{array}$ \\
\hline Subject L3 & & $\begin{array}{l}\text { Oh, the central tendency that Rangga } \\
\text { hopes to use by his teacher }\end{array}$ \\
\hline
\end{tabular}

Besides being able to recognize problems well, the subject was also able to devise appropriate strategies to be able to resolve the problem. The subject explained his idea in solving the problem that he used assumptions to determine the eighth value. Subjects got the eighth score by finding the mean of the seven known data. He used these results as an eighth possible score assumption. Then the subject calculated the central tendency with eight data. As in the following interview excerpt where the subject explained the solution strategy.

Subject L3 : First, I need to assume, if after 7 times Rangga test gets scores like this, what the estimate of Rangga's eighth score. To be safe I look for the eighth score from an average (mean) of 7 previous tests. So the eighth score is an average (mean) of 7 tests.

Then, I looked the mean fo eight scores and it turned out to be the same (with the mean for seven scores). I continue to search for the median to get the best score. I do not use mode because there are no equal scores. So I use the median. If you use the mean the score is the same. Thus, I use the median so that the score is higher

In the building-with process, the subject could execute the strategies he had compiled in the process of recognition. Likewise, when the subject was asked whether the steps of work that he did was right the subject was also able to give a reason.

Subject L3 : I'm sure my answer is correct because, in terms of the formula, the steps are correct
In the last process or awareness, the subject had to do was to conclude the truth of the claim he submitted by showing evidence. The subject could give the right conclusions from the results of calculations that he had done to support the claims he made. Even when researchers doubted the answer, the subject was still able to maintain the answer with rational reasons as in the following interview excerpt.

Researcher : Why did you say at the beginning (Figure 1) that to calculate the final score of Rangga's test, you used the mean but at the end, you mentioned to use the median?

Subject L3 : Back to my previous statement. To be safe I determine the eighth score using the mean. If you use the median, only the middle score will be detected. It does not represent all values. Only after the eighth score was determined, I choose the median to calculate the final value because the value was higher.

\section{Level 2's Subject Mathematical Justification}

Students who were included in this level were students who determined the central tendency by calculating or analyzing the seven test scores that had been given. Although the reasons that given were accompanied by the exact calculation results, because students did not consider the eighth score, the claims and arguments submitted were included in level 2. Besides, those students included in this level were students whose answers contained errors or misconceptions.
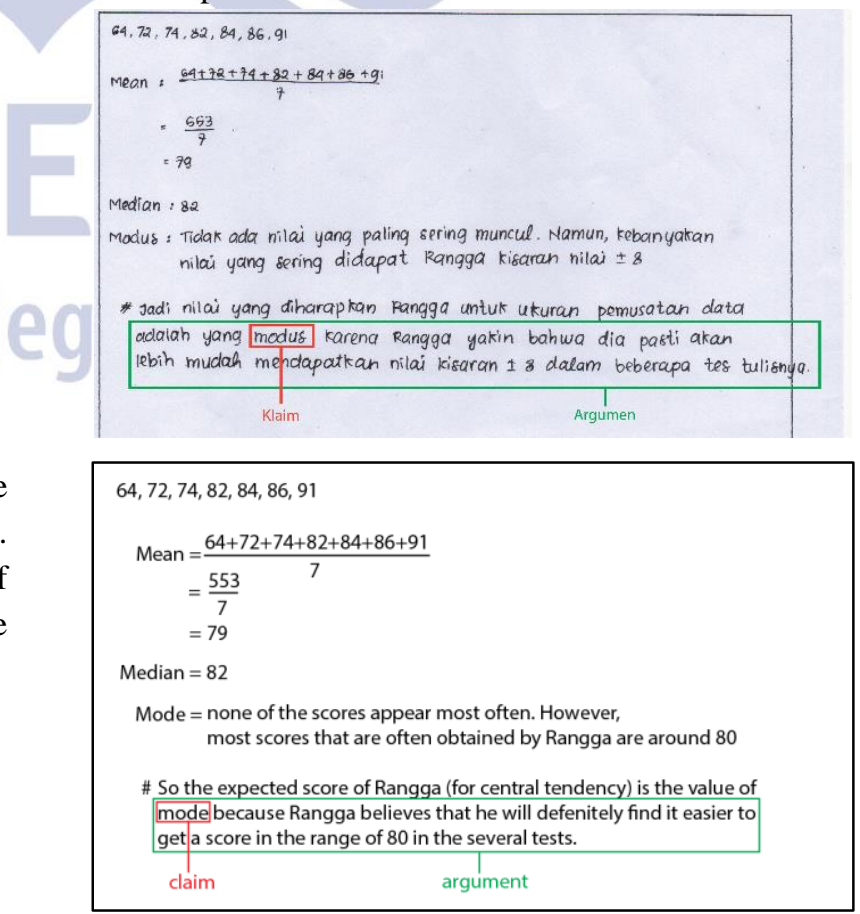

Figure 2. Level 2's Subject Work Result 
Figure 2 shows the answers from level 2's subject. The subject could recognize the problem. The subject could point out the main issues of the problem discussed in the test problem so that the subject could determine the problem-solving strategy.

Subject L2 : The problem is to find the mean, median mode. So, the settlement plan is to find the value (of mean, median, mode) one by one and then conclude it

From the strategy he made, the subject could work on his strategy correctly. Likewise, when the subject was asked to show the truth of the results of his calculations, the subject explained that as long as the formula he used was correct, the calculation results would be correct.

Researcher : In your opinion, is the way you do it already correct?

Subject L2 : of course, because I calculate it according to the formula

But unfortunately, when the subject was asked to deduce the results of the calculation, the subject seemed to have a misconception. This error caused the arguments given by the subject to be less precise. Because of this, although the subject could provide claims and their arguments, the arguments he made became less valid. As seen in the following interview excerpt, the subject chose the mode with the reason that the scores of 80 appear at the most despite varying values. So, even though the subject could make the process of awareness, the process he did was less than perfect because of a misconception of the concept.

Researcher : In the end, you choose the mode as a

Subject L2 : Because of the most scores appear around 80. So I choose the mode

\section{Level 1's Subject Mathematical Justification}

Students included in level 1 were students who made claims but were not accompanied by arguments. There were two types of answers given by students that were included in level 1. Some students' answers were not accompanied with arguments and some others answer that the central tendency was chosen with the reason 'easily calculated' or 'seems accurate' or 'because of this central tendency were commonly used 'and various other subjective reasons. As the answer to level 1's subject shown in Figure 3, where the subject provided subjective reasons to support the reason.
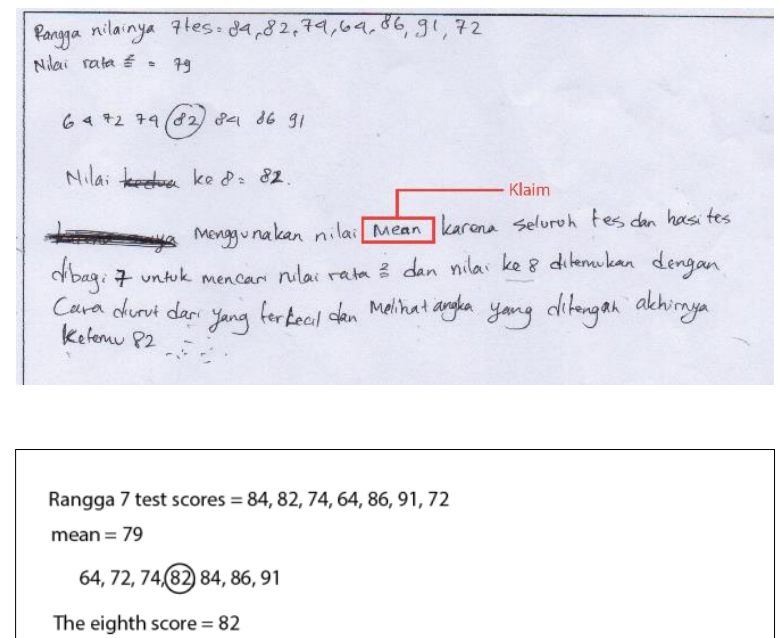

use the mean because all tests and test results are divided by 7 to find the mean value and the eighth score is found by sorting from the smallest and looking at the middle number finally found 82

\section{Figure 3. Level 1's Subject Work Result}

The subject could point out the main issues in the problem requested in the test problem. Although the subject could determine the main issues of the problem on the test problem, the subject had difficulty in developing ideas to determine what strategy should be done. So even though it was not perfect, the building-with process on level 1's subject was still visible.

Subject L1 : It is expected that 7 test scores are calculated using the mean, median or mode to find the (final) value.

Subject L1 : Here, the value is only 7 but why is it mentioned that the test is 8 times. So I'm confused. So what is being sought is the final score or the eighth score?

In the development process, after the subject determined the value of each measure of centralization of data, the subject brought up new information that was not included in the problem, namely the KKM (minimum learning master standard) value. From the results of the calculation of the subject obtained the mean value equal to 79 and the median value equal to 82 . After that, the subject chose the value of 82 as the eighth score because 82 was above the KKM value.

Subject L1 : So first I look for the average or mean, I get 79. Then it is sorted to find the middle value or median, I get 82 .

Researcher : [Referring to Figure 3 where 82 is the 8 th score] Well you got the 82 from the median, now even though you are also calculating the mean, why do you use the median, why not the mean? 


\section{Subject L1 : Because in my opinion, the score of 82 is above the KKM \\ Researcher : What is the KKM value? \\ Subject L1 : 79 \\ Researcher : Where's that from? \\ Subject L1 : From school}

Although the subject could think of the eighth value, the subject failed in interpreting the results of calculations that he had done. The subject considered determining the central tendency to calculate the final score and determine the eighth score were two separate things. Even the reason for choosing the mean of central tendency was not accompanied by supporting evidence but subjective subject opinions. So, level 1's subject could not do the final process of mathematical justification that was awareness.

Subject L1 : I choose the mean to determine the final value because usually the mean is used to calculate the average final score, for the eighth score I choose the median. After all, the value is above the KKM. If you choose to use the mean (when the data is still 7) the eighth score is 79, smaller than the median.

\section{Level 0's Subject Mathematical Justification}

Students who did not make a claim were classified as level 0 mathematical justification. Half of the students that included in level 0 only gave the calculation results of each central tendency without any reason. While the rest count to determine the eighth score which was not what was asked in the test problem.

Figure 4 shows the answer from subject level 0. Based on the subject's answer, the subject seemed to have an error recognizing the problem. In Figure 4, the subject could make assumptions for the eighth value which was then used again in calculating the size of the concentration of data as did the level 3's subject. Unfortunately the results of calculations that had been done by the subject were not interpreted according to what is asked in the test problem.

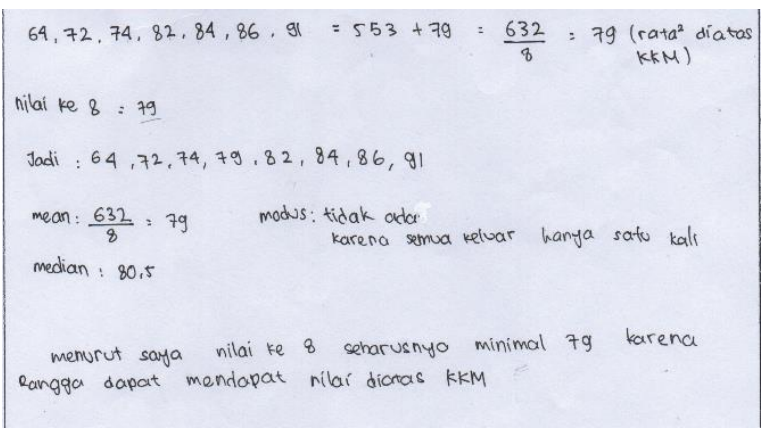

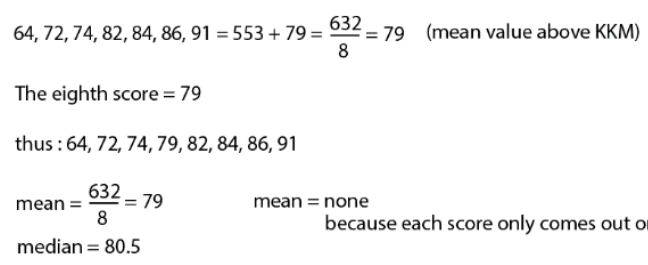

Figure 4. Level 0’s Subject Work Result

So even though the subject gave answers along with reasons, but the answers given by the subject did not contain claims so the subject did not answer as requested in the test problem. This is because from the beginning the subject had mistakenly recognized the problem in the test problem, the subject could not answer the test as requested. Also, if observed, the subject gave rise to an idea about $\mathrm{KKM}$ which was not mentioned at all in the test problem. So, it can be said that level 0's subject is not able to do any justification process because the subject failed to recognize the problem.

Researcher : Please conclude and briefly explain the results of your work

Subject LO : Um ... so in my opinion, this is Rangga, who only took the test 7 times, but he was asked about the eighth score. To be able to determine the eighth score, I use the mean, so the eighth score is at least 79. Why is 79 because Rangga's minimum score is right on KKM, if more than 79 is okay, it means that Rangga's score is above KKM.

\section{Discussion}

The main key in solving mathematical justification test problem given to students is the accuracy of analyzing existing data to build arguments and get the right claims. The argument given must be based on the evidence shown through the calculation results so that the claim they made can be proven true. For students to be able to answer test questions, students must be able to identify problems correctly and be able to conclude from the results of the calculations they do.

The students who were included in level 3 and level 2 mathematical justifications could demonstrate the whole justification process. The students could recognize problems (recognize process), determine solutions and solve strategies well (building-with process), and the students could interpret the results of the calculations they had done (awareness process). The difference between level 3 and level 2 students lay in the mistakes made by students during the justification process. The students who 
were included in level 2 mathematical justification tend to make mistakes such as only considering seven data in their calculations or in calculating the median students forgot to rank them from the smallest data or other small mistakes. The disadvantage of level 3 students was that the students did not consider all the possibilities available for the eighth score, so the students only showed the choice of central tendency only for one case. Therefore, there were no students included in level 4.

The students who were included in level 1 showed the difficulty of the mathematical justification process in the third process, awareness. Although the students recognized the problems in the first process and show the results of calculations in the second process, the students failed to interpret the results of these calculations. Many students were still at level 1 because the students tend to describe how they got the answers instead of explaining why the strategy was used or why their answers were correct (Hamidy \& Suryaningtyas, 2016). While the students who were at level 0 showed the difficulty of the mathematical justification process of the first process, namely recognize. The students failed to recognize the problem so the answers given by students differed from what was asked by the problem. As a result, the students did not do the whole justification process especially the students were not able to interpret the results of these calculations.

There are still many students who are still included in the low level of mathematical justification (level 1 and level 0 ) in this study appear in line with the results of research conducted by Eko et. al. (2018). According to the results of the study, as many as $66 \%$ of 10th-grade high school students were able to solve problems but with incorrect justification. As in this study, $67 \%$ of students were included in the low-level justification (level 1 and level 0). The low level of student justification might be the result of students rarely justifying. The teacher is not accustomed to asking students why students use the strategy or why students believe that the answer is correct (Sarumaha, 2015; Eko et al., 2018). Students who are not accustomed to doing this cause low levels of student justification, low student justification indicates students are not able to do the whole justification process. Also, it seems that the environment in which students learn more or less influences the answers given by students. This is indicated by the emergence of a new idea, namely KKM, which is not mentioned in the test problem.

\section{CONCLUSIONS}

Based on the description above, of 122 high school students who were given the test only 21 students $(17 \%)$ were able to achieve level 3 mathematical justification while others were spread into level 2 by 19 students $(16 \%)$, level 1 by 57 students (47\%), and level 0 by 25 students (20\%). When reviewed through the mathematical justification process, the level 3's students can demonstrate the whole process of mathematical justification as well as the students who are included in level 2 with a different understanding of concepts owned by the students. While the students who are included in level 1 have difficulty in going through the process of awareness in which the students can not associate the results of calculations that have been done. While the students who are included in level 0 do not show any mathematical justification process.

\section{RECOMMENDATIONS}

Recommendation for teachers to be able to help students improve students' mathematical justification abilities are to familiarize students with asking questions that make students do mathematical justification, such as "why are you sure your answer is correct?" or "why did you use this step?".

Based on the information from the results of the interviews with the students, the students are not familiar with the given problem models. Learning models and appropriate question designs can be developed to help students get used to doing mathematical justification.

\section{REFERENCES}

Chua, B. L. (2016). Examining Mathematics Teachers' Justification and Assessment of Students, Justifications. (August).

Chua, B. L. (2017). A framework for classifying mathematical justification tasks. Cerme, 1-8.

Eko, Y. S., Prabawanto, S., \& Jupri, A. (2018). The role of writing justification in mathematics concept: The case of trigonometry. Journal of Physics: Conference Series, 1097(1). https://doi.org/10.1088/1742-6596/1097/1/012146

Furinghetti, F., \& Morselli, F. (2011). Johnny's Beliefs About Proof. 106-119.

Garfield, J. (2002). The challenge of developing statistical

reasoning. Journal of Statistics Education, 10(3). https://doi.org/10.1080/10691898.2002.11910676

Glass, B., \& Maher, C. A. (2004). Students' Problem Solving and Justification. International Group for the Psychology of Mathematics Education; 28th, Bergen, Norway, July 14-18, 2(1989), 463-470.

Hamidy, A., \& Suryaningtyas, S. (2016). Kemampuan Justifikasi Matematis Siswa Smp Pada Materi Segitiga. Prosiding Seminar Nasional Pendidikan Matematika Dengan Tema "Pengembangan 4C's Dalam Pembelajaran Matematika: Sebuah Tantangan Dalam Pengembangan Kurikulum Matematika" Pada Tanggal 28 Mei 2016 Yang Diselenggarakan Oleh Prodi Pendidikan 
Matematika Pascasa, (May 2016), 1-13. Retrieved from

Kidron, I., \& Dreyfus, T. (2010). Justification enlightenment and combining constructions of knowledge. Educational Studies in Mathematics, 74(1), 75-93. https://doi.org/10.1007/s10649-0099228-7

Lapointe, S. (2011). Justification and Proof. Bolzano's Theoretical Philosophy, 91-101. https://doi.org/10.1057/9780230308640_8

Lin, P. (2016). Enhancing Students' Mathematical Conjecturing and Justification in Third-Grade Classrooms : The Sum of Even / Odd Numbers. 9(1), $1-15$.

Lo, J. J., Grant, T. J., \& Flowers, J. (2008). Challenges in deepening prospective teachers' understanding of multiplication through justification. Journal of Mathematics Teacher Education, 11(1), 5-22. https://doi.org/10.1007/s10857-007-9056-6

NCTM. (2000). Principles and Standards for School Mathematics.

Pamungkas, M. D., Juniati, D., \& Masriyah, M. (2018). Mathematical Justification Ability: Studentsr Divergent and Convergent Process in Justifying
Quadrilateral. 157(Miseic), 38-41. https://doi.org/10.2991/miseic-18.2018.10

Rosidah, Ketut Budayasa, I., \& Juniati, D. (2018). An Analysis of Statistical Reasoning Process of High School Students in Solving the Statistical Problem. Journal of Physics: Conference Series, 1028(1). https://doi.org/10.1088/1742-6596/1028/1/012125

Sarumaha, Y. A. (2015). Justifikasi dalam Pembelajaran Matematika. Prosiding Seminar Nasional Etnomatnesia, (ISBN: 978-602-6258-07-6), 286295.

Staples, M., \& Bartlo, J. (2010). Justification as a learning practice: Its purposes in middle grades mathematics classrooms. (March 2010).

Supriani, Y., Fardillah, F., rmudi, T., \& Herman, T. (2019). Developing Students' Mathematical Justification Skill Through Experiential Learning. Journal of Physics: Conference Series, 1179, $012070 . \quad$ https://doi.org/10.1088/1742$6596 / 1179 / 1 / 012070$

Weiss, N. A. (2012). Elementary Statistics 8th edition. In Journal of Chemical Information and Modeling (8th ed., Vol. https://doi.org/10.1017/CBO9781107415324.004

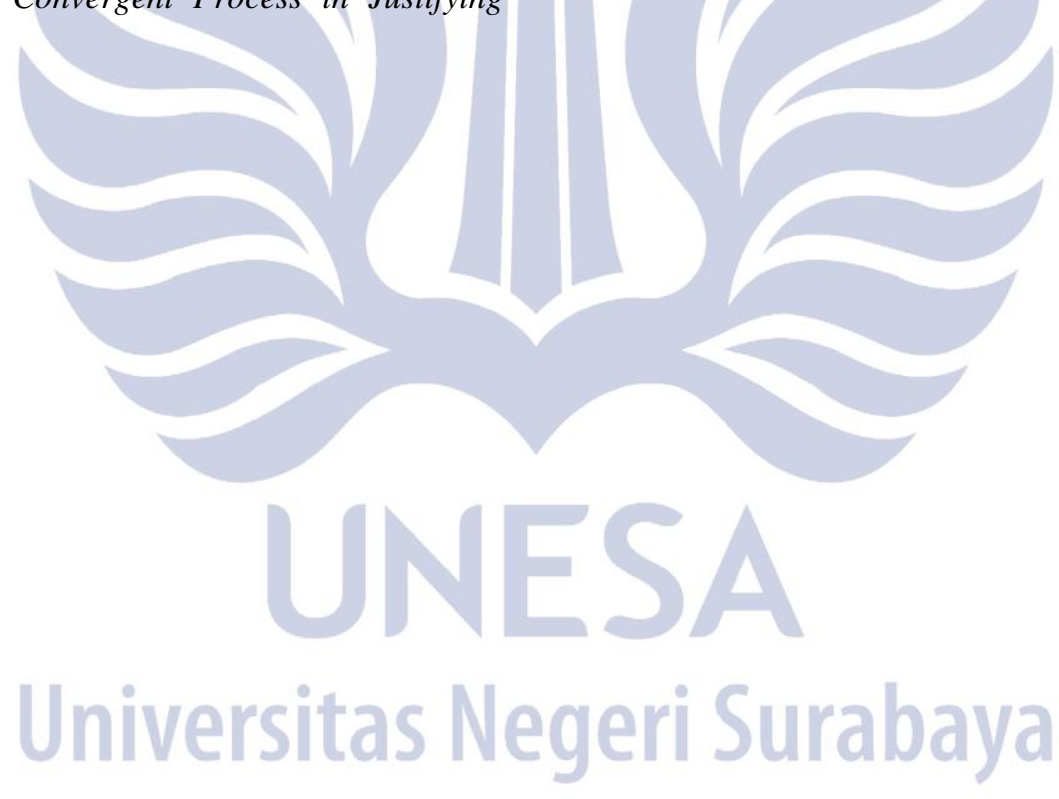

